\title{
FINITE AND BOUNDARY ELEMENT ANALYSIS OF CRACK CLOSURE
}

\author{
Mateusz Holek, Piotr FedelińSki ${ }^{*}$ \\ Department of Computational Mechanics and Engineering, \\ Silesian University of Technology, Konarskiego 18A, 44-100 Gliwice, Poland \\ *Corresponding author: piotr.fedelinski@polsl.pl
}

\begin{abstract}
The aim of this work is an analysis of contact pressure between crack surfaces and its influence on effective elastic properties of materials with randomly distributed cracks. The finite element method (FEM) and the boundary element methods (BEM) are applied to the numerical analysis of materials, and the results are compared. Three numerical results are presented. The accuracy of contact pressure obtained by numerical solutions is verified for a single inclined crack in an infinite plate subjected to compression by comparison with an analytical solution. The influence of angle between cracks and directions of compressive loading on contact pressure for a branched crack in a rectangular plate is studied. The effective Young moduli and Poisson ratios for a rectangular plate with randomly distributed cracks are computed. The plate contains intersecting cracks which are in contact when the plate is subjected to tension or compression.
\end{abstract}

Key words: Crack, Contact, Effective properties, Finite element method, Boundary element method

\section{INTRODUCTION}

Fracture mechanics is a field of science that is becoming increasingly important. Structures must withstand different types of loads and expectations for a constantly extending product life it is very important to predict the initiation and propagation of cracks. Studies on simple models such as plates allow for predicting crack behaviour.

After loading a cracked material, the crack surfaces can touch each other. The crack contact affects the stress distribution, in particular stress intensity factors (SIF), and the overall elastic properties of the material (Nemat-Nasser \& Hori, 1999). Branched or intersecting cracks can contact even when the material is subjected to tension. The purpose of this work was to analyse contact forces of crack surfaces and their influence on elastic effective properties.

Usually, the contact area and the distribution of contact forces are not known. Due to the com- plexity of the problem, computational incremental and iterative procedures are applied. Lee (1996) analysed plates with internal and edge cracks subjected to compressive and bending loadings using the dual boundary element method. The influence of crack size, angle and the coefficient of friction on SIF was studied. Tuhkuri (1997) used the same approach to analyse plates with a straight crack and a radial crack emanating from a circular hole in an infinite plate. Phan et al. (2003) used the symmetricGalerkin boundary element method to compute SIF of a single straight crack, a two-wing crack and a $\mathrm{T}$-crack in unbounded domains under compression. Sevostianov et. al (2011) studied the influence of the microstructure of the sintered metal fibers on elastic properties using analytical methods. The effect of relative volume of pores, pore shapes and relative length of crack branches, which depend on the temperature of sintering, was analysed. 
Fedeliński (2011) computed by the dual boundary element method effective elastic properties and SIF for representative volume elements (RVE) with randomly distributed cracks. The cracks having the same length, randomly distributed, parallel or randomly oriented were considered. The influence of density of cracks on the effective Young moduli, the effective Poisson ratios and SIF was presented. Fedeliński (2017, 2019b) considered sintered metal fibers with voids and branched cracks grooving from their centers. The RVE containing large number of regularly distributed branched cracks were investigated. The influence of void shapes and dimensions of the crack branches on SIF and elastic properties were studied. Fedeliński (2019a, 2019b) presented the analysis of plates with cracks subjected to compressive static loadings. The numerical examples of a single inclined crack in an infinite plate, a branched crack in a rectangular plate and multiple parallel inclined cracks in a square plate were presented. Contact forces, stress intensity factors and effective elastic properties were computed. An influence of direction of loading and orientation of cracks on stresses and overall elastic properties was studied.

The original contribution of this work is a comparison of the FEM and BEM solutions of crack contact problems, an analysis of contact forces for branched cracks and its influence on effective elastic properties.

\section{NUMERICAL IMPLEMENTATION OF THE FEM AND BEM FOR CRACK CLUSURE}

The plates with cracks are analysed by the finite element method and the dual approach of the boundary elements method.

The software Ansys 18.2 is used in the finite element analysis. The following contact parameters in Ansys 18.2 code are used: contact class - surface to surface, contact type - frictionless, formula - normal Lagrange and penetration and opening - close to zero (Dill, 2011). In the FEM analysis eight-node quadrilateral elements are applied.

The BEM requires discretization of external boundaries of plates and boundaries of cracks (Aliabadi, 2002). Three-node line elements are applied to analyse two-dimensional problems. The variations of boundary coordinates, displacements and tractions are interpolated using quadratic shape func- tions and nodal values. The relations between boundary displacements and tractions are expressed by the displacement and traction boundary integral equations (Portela \& Aliabadi, 1992). Direct solutions are displacements and tractions for boundary nodes. The standard BEM computer code was developed to take into account contact of crack surfaces (Fedeliński, 2019a). Contact forces are determined using the iterative procedure. In each iteration, the relative displacements of pairs of nodes on opposite crack surfaces in the normal and tangential directions are computed. When the opening is negative, the crack closure occurs. In this case, the pair of nodes is subjected to small normal tractions, which reduce overlapping of crack edges. The iterative process is repeated until the crack opening for the whole crack is positive. The increase of the crack tractions is constant and is assumed to be a fraction of the applied external traction.

In the considered numerical examples frictionless contact of crack surfaces is assumed.

\section{NUMERICAL EXAMPLES}

Three numerical examples are shown in this chapter. Each example presents a comparison of the FEM and BEM solutions. The aim of the first example - an infinite plate with a single inclined crack - is to verify the accuracy of the FEM analysis of contact forces by comparison with an analytical solution. The second example - a rectangular plate with a branched crack - shows the comparison of contact forces and an influence of angle between branches and direction of compressive loading on contact forces. The third example - a rectangular plate with randomly distributed straight cracks - presents the effective elastic properties computed for different types of loading.

The material of plates is linear-elastic, homogenous and isotropic, the plates are in plane strain conditions and the Poisson ratio is $v=0.3$.

\subsection{Plate with a single inclined crack}

An infinite plate with a single straight inclined crack is analysed. The crack is inclined at an angle $\alpha$ to the $x_{1}$ axis and the following angles are considered $\alpha=30^{\circ}, 45^{\circ}$ or $60^{\circ}$. The length of the crack is $2 a$ and the external dimensions of the plate are $2 w$ and $2 h(w=h)$. In order to model the infinite plate very large dimensions of the plate are assumed $w / a=$ 50. The dimensions of the plate and the crack are 
shown in figure 1 . The plate is loaded with boundary tractions $p_{1}$ in the horizontal direction, as shown in figure 2. The edge of the crack is divided into 200 finite elements or 10 boundary elements.

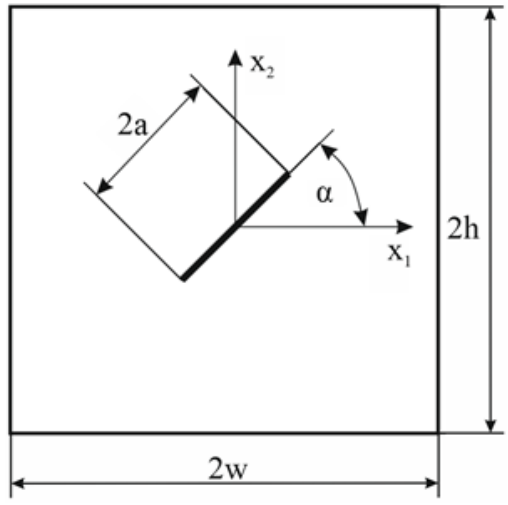

Fig. 1. Plate with a single inclined crack-dimensions.

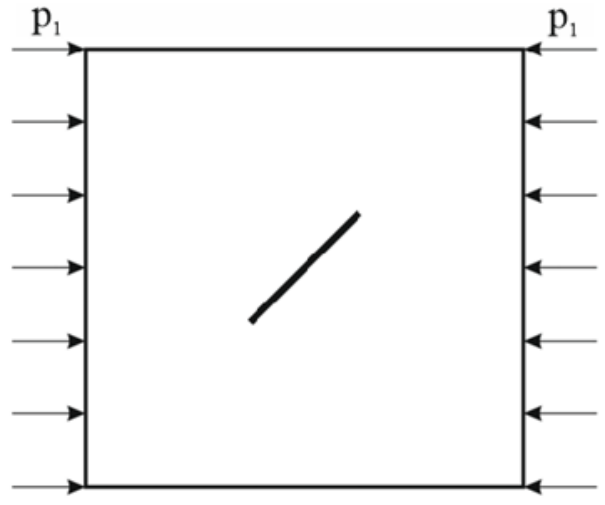

Fig. 2. Plate with a single inclined crack - traction boundary conditions.

The normal pressure $t_{n}$ in the centre of the crack computed by the FEM is compared with the BEM results (Fedeliński, 2019a) and the analytical solution (Melville, 1977) given by the equation:

$t_{n}=p_{1} \sin ^{2} \alpha$

The comparison of the normalised normal contact pressures $t_{n} / p_{1}$ is presented in table 1 . The results obtained by the analytical, the BEM and the FEM solutions are very similar. This simple numerical example demonstrates very high accuracy of numerical methods for the analysis of cracks in compression.

Table 1. Data used for material description in numerical modeling.

\begin{tabular}{|c|c|c|c|}
\hline \multirow{2}{*}{ angle $\alpha$} & \multicolumn{3}{|c|}{ normalised normal pressure on the crack $t_{n} / p_{1}$} \\
\cline { 2 - 4 } & analytical & BEM & FEM \\
\hline $30^{\circ}$ & 0.250 & 0.250 & 0.250 \\
\hline $45^{\circ}$ & 0.500 & 0.500 & 0.499 \\
\hline $60^{\circ}$ & 0.750 & 0.750 & 0.749 \\
\hline
\end{tabular}

\subsection{Plate with a single branched crack}

A rectangular plate contains a single branched crack in the centre, as shown in figure 3 . The external dimensions of the plate are $2 w$ and $2 h(h / w=$ 0.8 ). The length of horizontal branch is $a$ and the lengths of two symmetrically slanted branches is $b$. The length of crack branches is equal $(a=b)$ and $a / w=0.5$. The angle between the branches is $2 \alpha$ and three different angles are considered $\alpha=30^{\circ}, 45^{\circ}$ or $60^{\circ}$. Two types of boundary conditions are studied: the compressive tractions $p_{1}$ are applied in the horizontal direction or the tractions $p_{2}$ are applied in the vertical direction along the parallel edges of plate, as shown in figure 4.

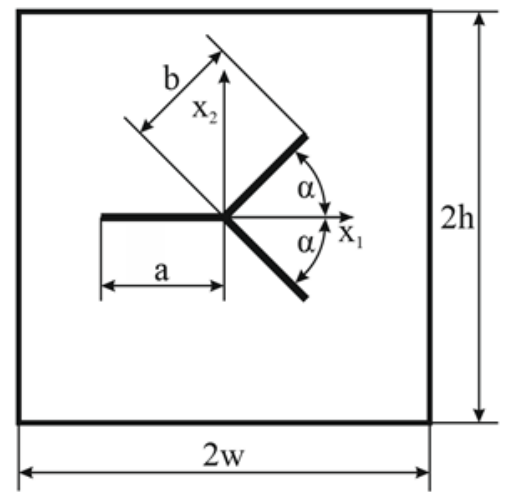

Fig. 3. Plate with a single branched crack-dimensions.

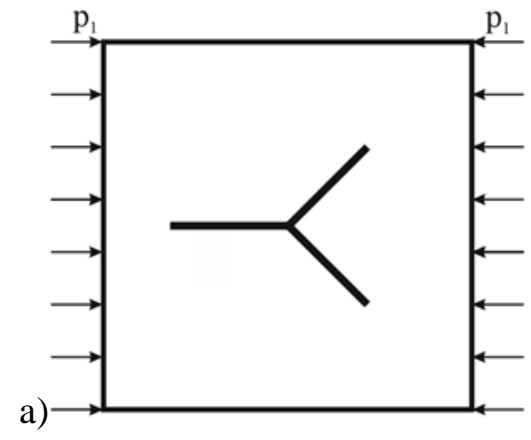

b)

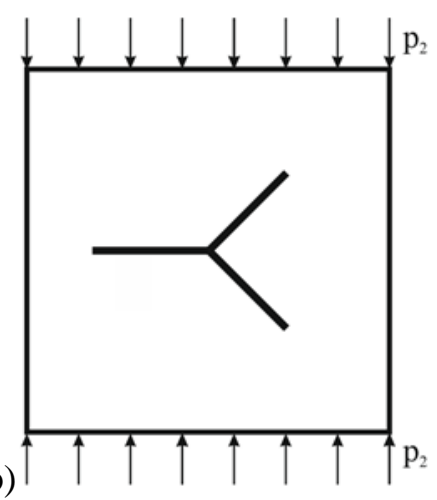

Fig. 4. Plate with a single branched crack - traction boundary conditions: a) loading in $x_{1}$ direction, $b$ ) loading in $x_{2}$ direction. 
The aim of this numerical example was to verify accuracy of the FEM solutions by comparison with the BEM solutions (Fedeliński, 2019a). The edge of crack branch was divided into 200 finite elements or 10 boundary elements.

Figure 5 shows the distributions of normalized contact tractions $t_{n} / p$ along the edges for $\alpha=45^{\circ}$ obtained by the FEM and BEM.

a)
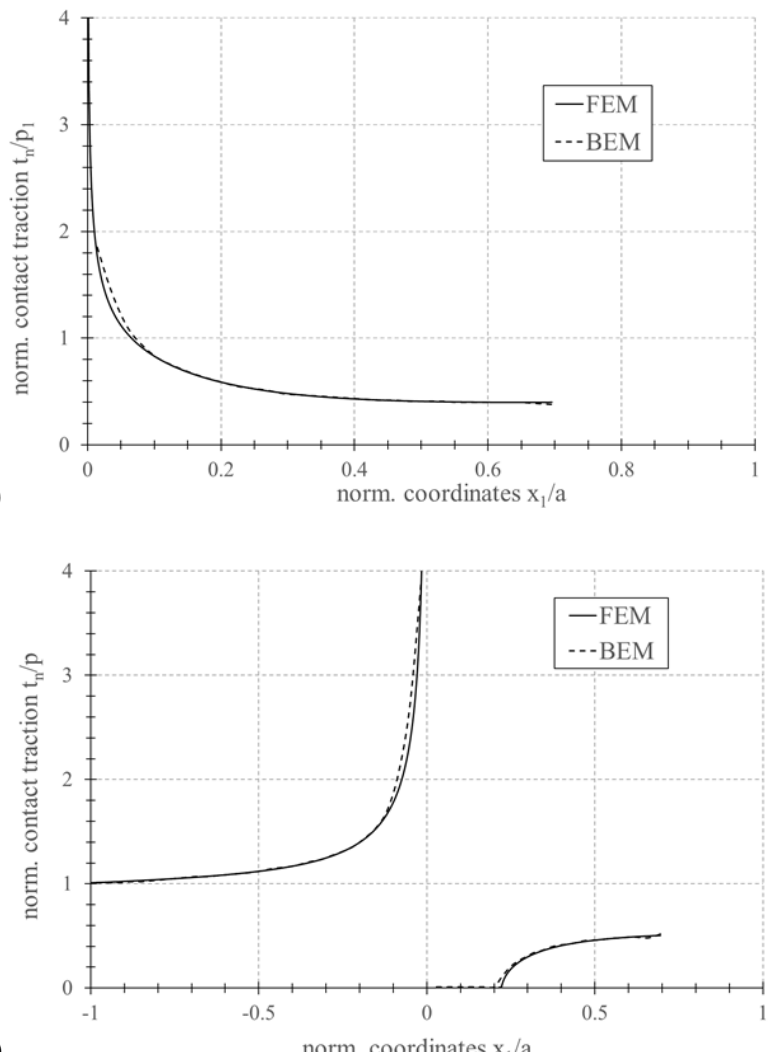

b)

norm. coordinates $\mathrm{x}_{1} / \mathrm{a}$

Fig. 5. Normalized contact tractions th/p for the plate with a single branched crack obtained by the FEM and BEM: a) tractions in $x_{1}$ direction, $b$ ) tractions in $x_{2}$ direction.

For the horizontal loading the contact occurs only along the inclined branches, and the larges values of tractions are near the centre of crack. For the vertical loading the contact occurs along the whole horizontal branch and partially along the inclined branches. The larges tractions are along the horizontal branch near the centre of crack and the value of normalized tractions near the crack tip tends to 1 . The agreement of the FEM and BEM solutions is very good.

Figure 6 shows the normalized contact tractions $t_{n} / p$ for different values of angle $\alpha$ obtained by the FEM. The largest tractions for the horizontal loading $p_{1}$ are for the angle $\alpha=60^{\circ}$. For the vertical loading the angle $\alpha$ has small influence on traction distribution along the horizontal branch. The largest trac- tions along the inclined branches are for the angle $\alpha$ $=30^{\circ}$.

a)

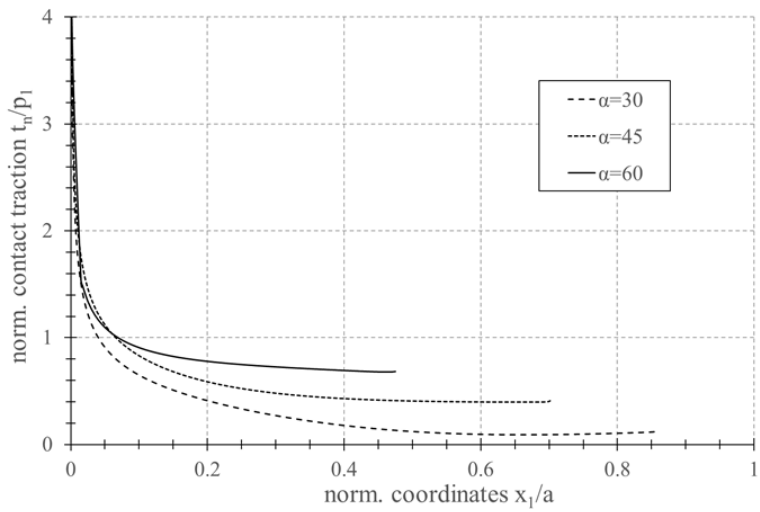

b)

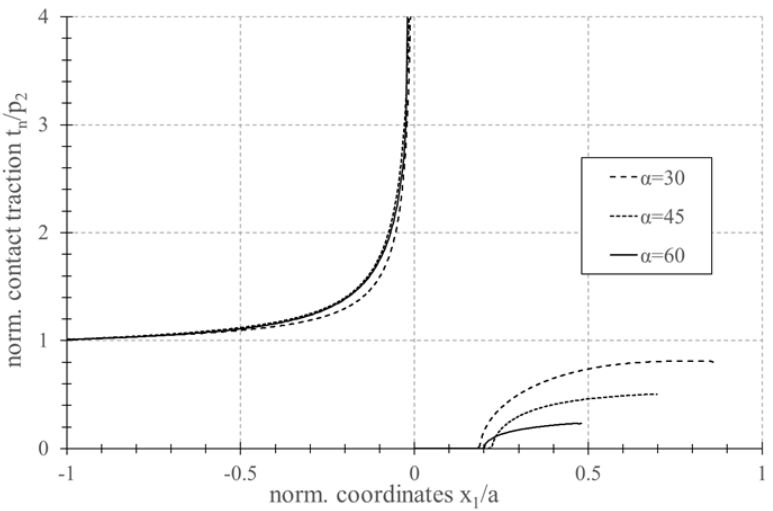

Fig. 6. Normalized contact tractions $\mathrm{tn} / \mathrm{p}$ for the plate with a single branched crack for different values of angle $\alpha: a)$ tractions in $x_{1}$ direction, $b$ ) tractions in $x_{2}$ direction.

\subsection{Plate with randomly distributed cracks.}

A square plate of width $2 w$ and height $2 h(w=h)$ contains 20 randomly distributed straight cracks of length $2 a(a / w=1 / 5)$, as shown in figure 7 . The plate contains 3 pairs of intersecting cracks. The edges of the cracks are divided into 200 finite elements or 8 boundary elements.

In order to determine the effective elastic properties of cracked plate, the normal tractions $p_{1}$ are applied in the $x_{1}$ direction and the tractions $p_{2}$ are applied in the $x_{2}$ direction, as shown in figure 8 . The extension and compression of the plate are considered. The plates are supported at the edges along the horizontal and vertical lines of symmetry. In the case of extension or compression, contact of crack edges of intersecting cracks occurs.

The displacements of plate boundaries calculated by the FEM and BEM are used to determine average strains and effective Young's moduli and Poisson's ratios. The properties are normalized with respect to the Young modulus $E_{0}$ and the Poisson ratio $v_{0}$ of material without cracks. Three different 
cases were considered: extension without contact, extension with contact and compression with contact of crack surfaces. The results obtained for the plate loaded in the $x_{1}$ direction are shown in table 2 and for the loading in the $x_{2}$ direction in table 3 . The initial and deformed cracked plates loaded in the $x_{1}$ direction, analysed by the BEM for three considered cases are shown in figure 9.

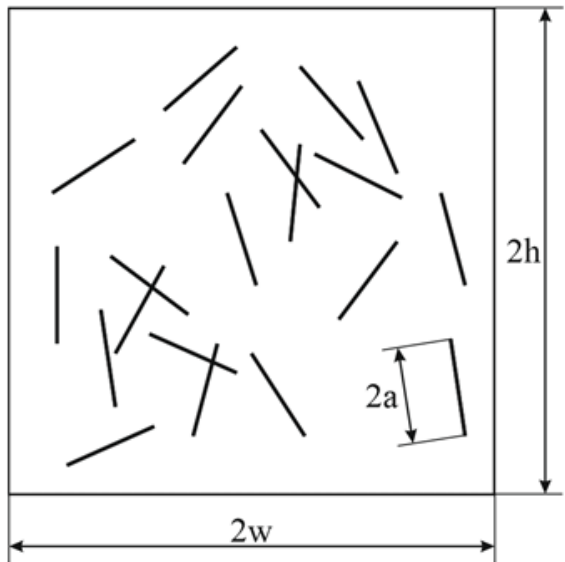

Fig. 7. Plate with randomly distributed cracks - dimensions.
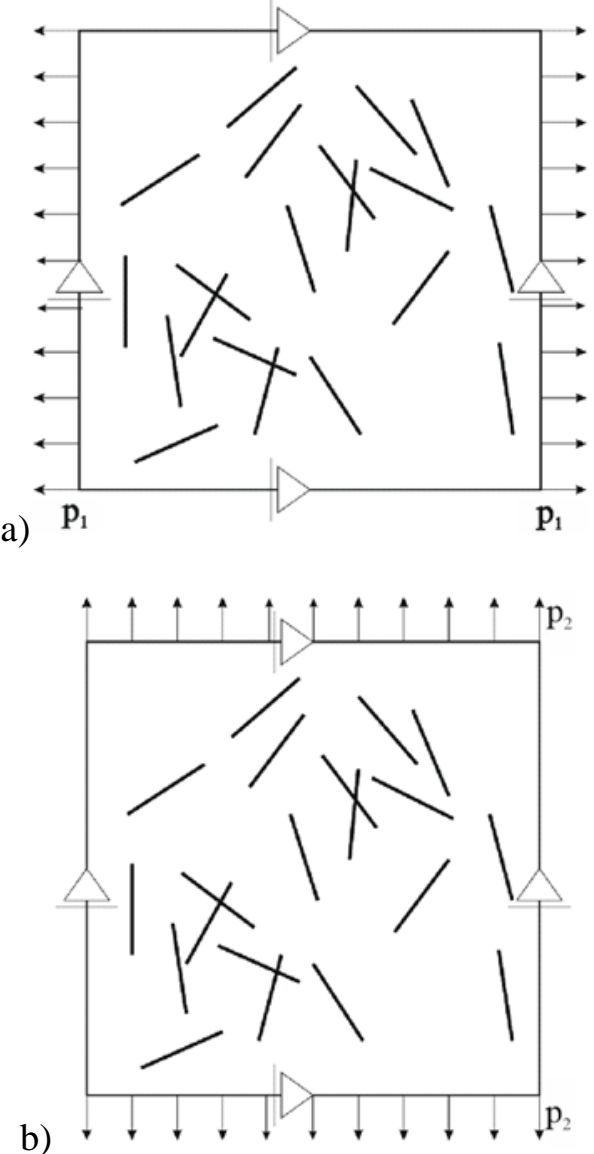

Fig. 8. Plate with randomly distributed cracks - traction boundary conditions: a) tractions in $x_{1}$ direction, $b$ ) tractions in $x_{2}$ direction.

Table 2. Effective elastic properties for the plate with randomly distributed cracks for three different types of loading in the $x_{1}$ direction.

\begin{tabular}{|c|c|c|c|c|}
\hline method & effective property & $\begin{array}{c}\text { extension } \\
\text { without contact }\end{array}$ & $\begin{array}{c}\text { extension } \\
\text { with contact }\end{array}$ & $\begin{array}{c}\text { compression } \\
\text { with contact }\end{array}$ \\
\hline FEM & $E_{1} / E_{0}$ & 0.425 & 0.435 & 0.829 \\
\hline BEM & $E_{1} / E_{0}$ & 0.428 & 0.434 & 0.824 \\
\hline FEM & $v_{12} / v_{0}$ & 0.477 & 0.401 & 1.396 \\
\hline BEM & $v_{12} / v_{0}$ & 0.469 & 0.398 & 1.398 \\
\hline
\end{tabular}

Table 3. Effective elastic properties for the plate with randomly distributed cracks for three different types of loading in the $x_{2}$ direction.

\begin{tabular}{|c|c|c|c|c|}
\hline method & effective property & $\begin{array}{c}\text { extension } \\
\text { without contact }\end{array}$ & $\begin{array}{c}\text { extension } \\
\text { with contact }\end{array}$ & $\begin{array}{c}\text { compression } \\
\text { with contact }\end{array}$ \\
\hline FEM & $E_{2} / E_{1}$ & 0.601 & 0.635 & 0.827 \\
\hline BEM & $E_{2} / E_{1}$ & 0.600 & 0.625 & 0.822 \\
\hline FEM & $v_{21} / v_{0}$ & 0.675 & 0.460 & 1.472 \\
\hline BEM & $v_{21} / v_{0}$ & 0.661 & 0.454 & 1.476 \\
\hline
\end{tabular}




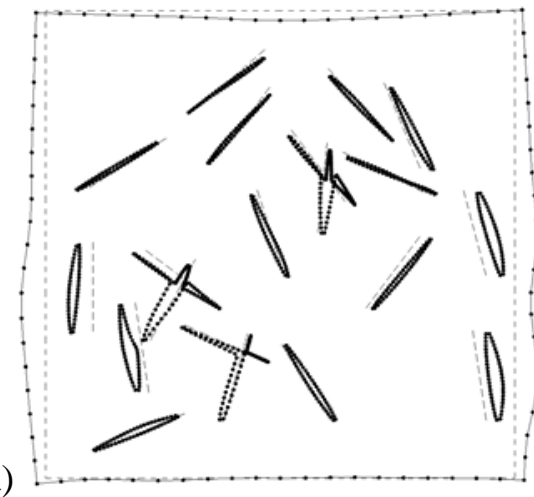

a)

b)

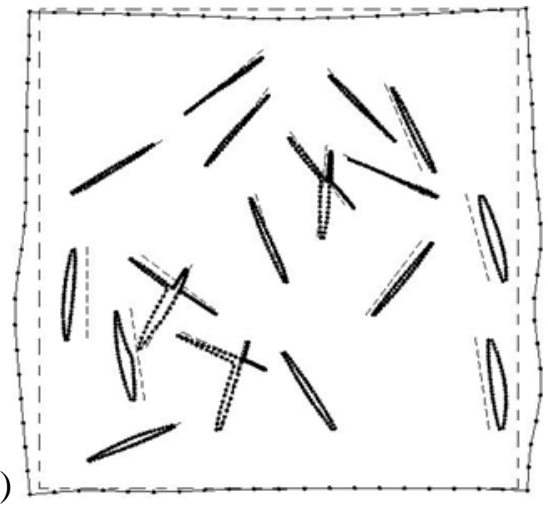

c)

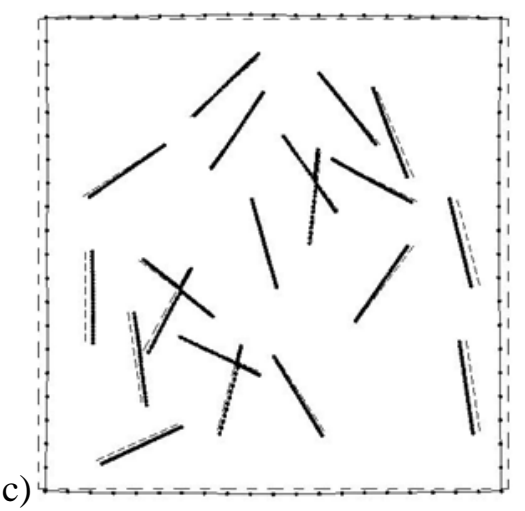

Fig. 8. Plates with randomly distributed cracks for three different types of loading in direction $x_{1}$ analysed by the BEM (initial shape-dashed line, deformed shape-continuous line): a) extension without contact, b) extension with contact, $c$ ) compression with contact.

Contact of crack surfaces slightly increases the Young moduli and significantly decreases the Poisson ratios for the plates subjected to tension. The Young moduli and Poisson ratios of the considered plate subjected to compression are much larger than the plate subjected to tension.

Effective properties of the material obtained by the FEM and BEM are in very good agreement.

The density of cracks can be described by the following parameter (Kachanov, 1992):

$\rho=\frac{1}{A} \sum_{i=1}^{n} a_{i}^{2}$ where: $A$ - the area of the RVE, $a_{\mathrm{i}}$ - the half-length of the crack, $n$ - the number of cracks.

In the considered case $a_{i}=a, n=20$ and $\rho=0.2$. The relative Young modulus of the cracked material can be estimated analytically (Kachanov, 1992) using:

- the non-interacting method:

$\frac{E}{E_{0}}=\frac{1}{1+\pi \rho}$

- the self-consistent method:

$\frac{E}{E_{0}}=1-\pi \rho$

- the differential method:

$\frac{E}{E_{0}}=e^{-\pi \rho}$

The relative Young modulus $E / E_{0}$ for the considered density of cracks calculated using the noninteracting method is 0.614 , the self-consistent method -0.372 and the differential method -0.533 . The average relative Young modulus $E / E_{0}$ for the horizontal and vertical loading computed by the FEM is 0.513 and by the BEM is 0.514 . These results agree well with the estimation by the differential method.

\section{CONCLUSIONS}

Rectangular plates with a single straight crack, a branched crack and with randomly distributed straight cracks are considered in the paper. The influence of orientation of cracks on distribution of contact forces and the influence of crack contact on the effective Young moduli and Poisson ratios are investigated. The materials are analysed by the finite and boundary element method. The results obtained by the FEM and BEM are similar. The preparation of input data for BEM models is much simpler than for FEM models of materials, because only the outer boundaries of plates and cracks are divided into elements. They agree very well with the analytical solution for the single straight crack. The direction of loading has a significant influence on distribution of contact forces for the branched crack. The angle between branches influences only contact forces along slanted branches. The Young moduli and Poisson ratios for the considered material with randomly distributed cracks in compression are larger than in tension. 


\section{ACKNOWLEDGMENTS}

The scientific research is financed by National Science Centre, Poland, in years 2016-2020, grant no. $2015 / 19 / \mathrm{B} / \mathrm{ST} 8 / 02629$.

\section{REFERENCES}

Aliabadi, M. H., 2002, The boundary element method, Vol. 2. Applications in solids and structures. John Wiley and Sons, Chichester.

Dill, E.S., 2011, The finite element method for mechanics of solids with ANSYS applications, CRC Press/Taylor and Francis Group.

Fedeliński, P., 2011, Analysis of representative volume elements with random microcracks. Chapter 17, in Computational Modelling and Advanced Simulation, Computational Methods in Applied Sciences 24, eds Murin, J., Kompiš, V., Kutiš, V., Springer Science+Business Media B.V., 333-341.

Fedeliński, P., 2017, Effective properties of sintered materials with branched cracks, AIP Conf. Proc., 1922, 030008-1-8.

Fedeliński, P., 2019a, Boundary element analysis of cracks under compression, AIP Conf. Proc. 2078, 020009-1-7.

Fedeliński, P. (Ed.), Dziatkiewicz, G., Fedeliński, P., Poteralski, A., Ptaszny, J., 2019b, Computer analysis and optimization of materials with complex properties and microstructures, Silesian University of Technology Press, Gliwice.

Kachanov, M., 1992, Effective elastic properties of cracked solids: critical review of some basic concepts, Appl. Mech. Rev., 45, 304-335.

Lee S.S., 1996, Analysis of crack closure problem using the dual boundary element method, Int. J. Frac., 77, 323-336.

Melville, P.H., 1977, Crack propagation and crack arrest in stress gradients, Int. J. Frac., 13, 165-181.

Nemat-Nasser, S., Hori, M., 1999, Micromechanics: Overall properties of heterogeneous materials, Elsevier.

Phan, A.-V., Napier, J.A.L., Gray, L.J., Kaplan, T., 2003, Stress intensity factor analysis of friction sliding at discontinuity interfaces and junctions, Comput. Mech., 32, 392-400.

Portela, A., Aliabadi, M.H., Rooke, D. P., 1992, The dual boundary element method: effective implementation for crack problems, Int. J. Num. Meth. Engnr., 33, 1269-1287.

Sevostianov, I., Picazo, M., Garcia, J. R., 2011, Effect of branched cracks on the elastic compliance of a material, Int. J. Engnr. Sc., 49, 1062-1077.

Tuhkuri, J., 1997, Dual boundary element analysis of closed cracks, Int. J. Numer. Meth. Engnr., 40, 2995-3014.

\section{METODA ELEMENTÓW SKOŃCZONYCH I BRZEGOWYCH W ANALIZIE ZAMYKANIA PĘKNIĘĆ}

\section{Streszczenie}

Celem pracy jest analiza sił kontaktowych między powierzchniami pęknięć i ich wpływu na zastępcze własności sprężyste materiałów z losowo rozmieszczonymi pęknięciami. Zastosowano metodę elementów skończonych (MES) i metodę elementów brzegowych (MEB) w analizie numerycznej materiałów i porównano wyniki obliczeń. Przedstawiono trzy przykłady numeryczne. Zbadano dokładność sił kontaktowych wyznaczonych metodami numerycznymi przez porównanie z rozwiązaniem analitycznym dla pojedynczego ukośnego pęknięcia w ściskanej nieskończonej tarczy. Badano wpływ kąta między pęknięciami i kierunków obciążenia ściskającego na siły kontaktowe rozgałęzionego pęknięcia w tarczy prostokątnej. Obliczono zastępcze moduły Younga i współczynniki Poissona prostokątnej tarczy z losowo rozmieszczonymi pęknięciami. Tarcza zawierała przecinające się pęknięcia, które stykają się, gdy tarcza jest rozciągana lub ściskana.

Received: February 22, 2020. Received in a revised form: April 4, 2020 Accepted: April 17, 2020. 